\title{
PENYELESAIAN SENGKETA PARA PIHAK DI BIDANG BISNIS \\ MELALUI ARBITRASE
}

\author{
Nurdin Siregar dan Radisman Saragih ${ }^{1}$
}

\begin{abstract}
Arbitration is a way of solving civil disputes outside the public courts based the arbitration agreement made in writing by the parties to the dispute. The arbitration agreement is an agreement in the form of the arbitration clause contained in a written agreement made by the parties before a dispute arises or a separate arbitration agreement made by the parties after a dispute arises. In everyday life with various activities of members of today's society, immense possibility of friction-friction in running business and trade that ended with disputes between members of the public and businesses. In efforts to completion, it would seem that this form of dispute diversity define the core issues then this diversity will be easy settlement with the provisions and rules of law that are sure to be able to look for the solution either arbitration or by mediation, consulting, negotiations, konsialiasi. The arbitration decision will be implemented after the verdict copy officially registered, but the arbitration ruling in accordance with the provisions of the law Arbitration can still be filed annulment if the decision is thought to contain elements, letters or documents are filed in the examination after the verdict recognized dinyataakan counterfeit or fake, after adjudication documents found prescriptive, which is hidden by the other party or the decision taken on the results of a ruse conducted by one of the parties in the dispute. That for legal certainty associated with the judiciary also good for the winning side and the decision is legally binding.
\end{abstract}

\section{Kata Kunci: Penyelesaian sengketa bisnis melalui arbitrase}

\section{Pendahuluan}

Kemajuan perdagangan di sebuah negara dapat memberikan manfaat bagi setiap warga negara, baik sebagai individu maupun korporasi. Dalam perjalannannya, tidak sedikit pula yang menimbulkan kerugian bagi pihak-pihak tertentu, yang diakibatkan perbedaan pendapat atau perbedaan penanfsiran tentang apa yang di setujui bersama dalam suatu perjanjian. Hal itu, berakibat muncul nya sengketa. Sengketa itu sendiri akibat dari salah satu pihak melakukan ingkar janji (wanprestasi) terhadap perjanjian yang disepakati para pihak. Perbedaan pendapat yang menimbulkan sengketa bagi para pihak tidak boleh dibiarkan berlarut-larut dan harus diselesaikan melalui suatu peradilan, dengan prinsip atau azas: cepat, sederhana dan biaya ringan.

\footnotetext{
${ }^{1}$ Nurdin Siregar, Dosen tidak tetap FH UKI

Radisman Saragih, Dosen tetap FH UKI
}

Dalam perkembangan penyelesaian sengketa dagang secara universal di kenal bentuk-bentuk penyelesaian sengketa yang homogen, salah satu yang cukup popular dan banyak diminati dewasa ini adalah melalui arbitrase.

Di kalangan sebagian pelaku bisnis, arbitrase merupakan praktek untuk mengatur sendiri penyelesaian sengketa yang akan timbul di kemudian hari, atas dasar perjanjian yang dibuat secara tertulis, dengan menunjuk arbiter atau para arbiter. Pengusaha tersebut berjanji akan menaati putusan yang diambil oleh arbiter yang telah mereka pilih.

Pilihan yang dilakukan oleh pengusaha menyelesaikan sengketa melalui Arbitrase, karena proses penyelesaian melalui litigasi cendurung memakan waktu yang cukup lama dan cendurung menimbulkan masalah baru karena sifatnya yang win-lose, tidak responsive, time consuming proses berperkara, dan terbuka untuk umum. 


\section{Permasalahan}

1. Apakah Lembaga Arbitrase dapat mengakhiri sengketa para pihak di bidang bisnis?

2. Bagaimanakah peranan pengadilan negeri untuk melaksanakan putusan arbitrase?

\section{Tujuan Penulisan}

1. Untuk mengetahui apakah Lembaga Arbitrase dapat mengakhiri sengketa para pihak dibidang bisnis.

2. Untuk mengetahui peranan peradilan umum/pengadilan negeri untuk pelaksanaan putusan Lembaga Arbitrase.

\section{Arbitrase}

Membahas arbitrase tak dapat dilepaskan dari peraturan perundang-undangan yang ada sebagaimana diatur dalam ketentuan pasal 377 HIR atau pasal $705 \mathrm{Rbg}$, kemudian diatur dalam UndangUndang RI No 14 Tahun 1970 tentang Pokok-Pokok Kekuasaan Kehakiman. Dalam penjelasan undangundang tersebut diuraikan tentang penyelesaian perkara di luar pengadilan atas dasar perdamaian atau melalui peradilan arbitrase. Namun, putusan arbiter tersebut baru memiliki kekuatan eksekutorial setelah memperoleh ijin atau perintah untuk dieksekusi (executoir) dari Pengadilan.

Selanjutnya, perubahan kedua dari UU RI No.14 Tahun 1970 tentang Pokok-Pokok Kekuasaan Kehakiman yang sekarang menjadi UU No.48 Tahun 2009 tentang Kekuasaan Kehakiman, pada Bab XII pasal $58 \mathrm{~s} / \mathrm{d}$ 61, mengatur penyelesaian sengketa di luar pengadilan, pasal 58 undang-undang tersebut berbunyi sebagai berikut:

'Upaya penyelesaian sengketa perdata dapat dilakukan diluar pengadilan Negara melalaui arbitrase atau allternatif penyelesaian sengketa”

Selanjutnya pasal 61 undang-undang tersebut mengemukakan sebagai berikut:

"Ketentuan mengenai arbitrase dan penyelesaian sengketa di luar Pengadilan sebagaimana dimaksud

dalam pasal 58, 59 dan pasal 60 diatur dalam undang-undang" yang dalam hal ini diatur dalam Undang-Undang No. 30 Tahun 1999 tentang Arbitrase dan Alternatif Penyelesaian Sengketa.
Menurut ketentuan pasal 5 ayat (1) UU No.30 Tahun 1999 tersebut yang pada pokoknya mengemukakan sengketa yang dapat diselesaikan melalui arbitrase hanya sengketa di bidang perdagangan dan mengenai hak yang menurut hukum dan peraturan perundang-undangan di kuasai sepenuhnya oleh pihak yang bersengketa. Kemudian menurut pasal 5 ayat (2) mengemukakan sengketa yang tidak dapat diselesaikan melalui arbitrase adalah sengketa yang menurut peraturan perundang-undangan tidak dapat diadakan perdamaian.

Meskipun tidak dijelaskan lebih lanjut, namun jika dihubungkan dengan penjelasan pasal 66 huruf $b$ undang-undang arbitrase maka batasan sengke- ta perdagangan adalah sengketa termasuk di dalam ruang lingkup hukum perdagangan adalah kegiatankegiatan antara lain di bidang perniagaan, perbankan, keuangan, penanaman modal, industri dan hak kekayan intelektual. $^{2}$

Selain sengketa tersebut ternyata di dalam praktek terdapat lebih banyak lagi jenis sengketa yang diselesaikan melalui arbitrase, hal ini dapat terjadi karena kehendak para pihak untuk memilih menyelesaikan sengketa mereka yang tidak pernah diperjanjikan sebelumnya. Ketika mereka sepakat untuk memilih jalan penyelesaian tidak melalui pengadilan melainkan melalui arbitrase, bentuk perjanjian yang demikian di kenal dengan istilah " Akta Kompromis " sebagaimana diatur di dalam pasal pasal 9 UU Nomor 30 Tahun 1999 tentang Arbitrase dan Alternatif Penyelesaian Sengketa. ${ }^{3}$

Menurut Priyatna Abdurrasyid, berdasarkan data dan hasil wawancara yang dilakukannya dengan BANI menyebutkan bentuk atau lingkup sengke- ta yang dapat diselesaikan melalui arbitrase selama ini tidak hanya yang tercantum di dalam ketentuan undang-undang melainkan lebih lebih luas lagi diantaranya sebagai berikut: konsultasi (consultation); keagenan (agency); perjanian dalam penjualan (licencing), perizinan usaha khusus (franchise), asuransi (insurance), kontruksi bangunan (construction); tenaga kerja (labour); perindustrian (industry); lingkungan hidup (environment); perakitan (fabrication);

\footnotetext{
${ }^{2}$ Cicut Sutiarso, Pelaksanaan Putusan Arbitrase dalam Sengketa Bisnis, Jakarta: Yayasan Pustaka Obor Indonesia, 2011, hal. 152153

${ }^{3}$ Ibid, hal.153.
} 
penyaluran barang (distribution); pelayaran (maritime/shipping); pengangkutan darat/air/udara (land/ sea/air trnasfortaion) pertambangan (mining); usaha patungan (joint venture) dan olah raga (sport). ${ }^{4}$

Penyelesaian sengketa di luar pengadilan bersifat tertutup untuk umum (close door session) dan kerahasiaan para pihak terjamin (confidenliality), proses beracara lebih cepat dan efisien. Proses penyelesaian diluar pengadilan ini menghindari kelambatan yang diakibatkan procedural dan adminsitratif sebagaimana beracara di pengadilan umum dan win-win solution. ${ }^{5}$

Menurut ketentuan pasal 60 UU No. 30 Tahun 1999 tentang Arbitrase dan Alternatif Penyelesaian Sengketa, menjelaskan Putusan Arbitrase bersifat Final dan mempunyai kekuatan hukum tetap dan mengikat para pihak. Kemudian pasal 61 undang-undang tersebut lebih lanjut mengemukakan dalam hal para pihak tidak melaksanakan putusan Arbitrase secara sukarela putusan dilaksanakan berdasarkan perintah Ketua Pengadilan Negeri atas permohonan salah satu pihak yang bersengketa.

Bahwa dari ketentuan pasal ini jika dicermati dengan saksama, maka dapat diperoleh pemahaman terhadap putusan Arbitrase dimaksud tidak ada lagi upaya hukum, dan pihak yang kalah harus melaksanakan putusan tersebut secara suka rela sebagaimana telah diperjanjikan tanpa mempersoalkan apakah perjanjian dibuat sebelum sengketa timbul sebagaimana diatur dalam Pasal 2 UU No: 30 Tahun 1999 tentang Arbitrase dan Alternatif Penyelesaian Sengketa, atau setelah sengketa terjadi berdasarkan ketentuan pasal 9 ayat (1) UU tersebut, karena menurut ketentuan pasal 61 sebagaimana dikemukakan diatas, jika para pihak tidak melaksanakan putusan Arbitrase secara suka rela, maka atas permohonan salah satu pihak yang bersengketa putusan dilaksanakan atas perintah Ketua Pengadilan Negeri.

Terhadap ketentuan pasal tersebut, jika dicermati dengan saksama, pelaksanaan terhadap putusan arbitrase tersebut tidak mutlak dapat dilaksanakan, dikarenakan adanya batasan waktu dan upaya hukum sebagaimana diatur dalam ketentuan pasal $70 \mathrm{~s} / \mathrm{d} 72$

\footnotetext{
${ }^{4}$ Priyatna Abdurrasyid, Badan Arbitrase Nasional Indonesia: Jakarta, 2009,h 19. Dalam Cicut Sutiarso, Pelaksanaan Putusan Arbitrase Dalam Sngketa Bisnis, hal. 153.

${ }^{5}$ Frans Hendra Winarta, Hukum Penyelesaian Sengketa, Jakarta: Sinar Grafika, 2012, hal. 9
}

undang-undang tersebut yang menyatakan sebagai berikut:

Terhadap putusan arbitrase para pihak dapat mengajukan permohonan pembatalan apabila putusan tersebut di duga mengandung unsur-unsur sebagai berikut:

Setelah putusan diambil ditemukan surat atau dokumen yang diajukan dalam pemeriksaan, setelah putusan dijatuhkan, diakui palsu atau dinyatakan palsu.

Surat atau dokumen yang diajukan dalam pemeriksaan, setelah putusan dijatuhkan, diakui palsu oleh pihak lawan atau.

Putusan diambil dari hasil tipu muslihat yang dilakukan oleh salah satu pihak dalam pemeriksaan sengketa.

Kemudian dalam penjelasan pasal 71 UU No.30 Tahun 1999 tentang Arbitrase dan Alternatif Penyelesaian Sengketa, mengemukakan sebagai berikut:

"Permohonan pembatalan hanya dapat diajukan terhadap putusan arbitrase yang sudah di daftarkan di Pengadilan. Alasan-alasan permohonan pembatalan yang disebut dalam pasal ini harus dibuktikan dengan putusan pengadilan. Apabila Pengadilan menyatakan bahwa alasan-alasan tersebut terbukti atau tidak terbukti, maka putusan pengadilan ini dapat digunakan sebagai dasar pertimbangan bagi hakim untuk mengabulkan atau menolak permohonan"

\section{Fleksibelitas Arbitrase dan Alternatif Penye- lesaian Sengketa}

Menurut ketentuan pasal 1 angka 1 UU No.30 Tahun 1999 tentang Arbitrase dan Alternatif Penyelesaian Sengketa, arbitrase adalah cara penyelesaian sengketa perdata di luar peradilan umum yang didasarkan pada perjanjian arbitrase yang dibuat secara tertuliss oleh para pihak yang bersengketa. Kemudian pada pasal 1 angka 3 undang-undang tersebut menyatakan, perjanjian arbitrase adalah suatu kesepakatan berupa klausula arbitrase yang tercantum dalam suatu perjanjian tertulis yang dibuat para pihak sebelum timbul sengketa, atau suatu perjanjian arbitrase tersendiri yang dibuat para pihak setelah timbul sengketa.

Dalam pasal 53 UU No 30 Tahun 1999, disebutkan, bahwa terhadap putusan arbitrase tidak dapat dilakukan perlawanan atau upaya hukum apapun. Se- 
dangkan pada pasal 60 undang-undang tersebutsecara tegas disebutkan, putusan arbitrase bersifat final dan mempunyai kekuatan hukum tetap dan mengikat para pihak. Dari ketentuan tersebut dapat dikatakan terhadap putusan arbitrase tidak dapat lagi dilakukan upaya hukum, sehingga pihak yang kalah dalam sengketa yang telah diputus oleh arbitrase secara suka rela harus mematuhi dan melaksanakan putusan arbitrase tersebut.

Selanjutnya dalam ketentuan pasal 70, menyatakan terhadap putusan arbitrase para pihak dapat mengajukan permohonan pembatalan apabila putusan tersebut diduga mengandung unsur-unsur antara lain sebagai berikut:

1. Surat atau dokumen yang diajukan dalam pemeriksaan, setelah putusan dijatuhkan, diakui palsu atau dinyatakan palsu.

2. Setelah putusan diambil ditemukan dokumen bersifat menentukan, yang disembunyikan pihak lawan, atau.

3. Putusan diambil dari hasil tipu muslihat yang dilakukan oleh salah satu pihak dalam pemeriksaan sengketa.

Dalam penjelasan pasal 70 menyataakan, "Permohonan pembatalan hanya dapat diajukan terhadap putusan arbitrase yang sudah didaftarkan di pengadilan. Alasan permohonan pembatalan yang disebut dalam pasal ini harus dibuktikan dengan putusan pengadilan. Apabila pengadilan menyatakan bahwa alasan-alasan tersebut terbukti atau tidak terbukti, putusan pengadilan ini dapat digunakan sebagai dasar pertimbangan bagi hakim untuk mengabulkan atau menolak permohonan."

Menurut pendapat Cicut Sutiarso, ukuran sebuah putusan arbitrase yang dikatakan final dan mempunyai kekuatan hukum tetap dan mengikat para pihak namun untuk dapat dilaksanakan harus terlebih dahulu didaftar di lembaga lain (Pengadilan Negeri), maka putusan yang demikian disebut putusan yang

mempunyai kekuatan hukum tetap semu, sehingga ada perbedaan antara pengertian mempunyai kekuatan hukum tetap bagi lembaga litigasi pengadilan yang dalam praktiknya langsung dilaksanakan oleh Ketua Pengadilan dengan cara berdasarkan prosedur eksekusi apabila perlu dilaksanakan dengan cara paksa dibantu dengan alat keamanan negara yaitu polisi. $^{6}$

Selanjutnya beliau mengemukakan tindakan pendaftaran putusan Arbitrase ke Pengadilan Negeri adalah merupakan keharusan yang berakibat apabila tidak dilakukan maka putusan Arbitrase yang bersifat terakhir dan mengikat tidak dapat dilaksanakan. Dalam Arbitrase telah terjadi suatu keadaan yang berbeda dengan Pengadilan Negeri yaitu putusan bersifat terakhir dan mengikat tidak bisa dikatakan mempunyai kekuatan hukum yang tetap, yang berarti belum bisa dilaksanakan secara paksa melalui prosedur eksekusi. $^{7}$

\section{Pilihan Penyelesaian Sengketa melalui Arbitrase}

Masyarakat Indonesia di dalam menyelesaiakan sengketa bisnisnya sudah mulai banyak yang memilih penyelesaian melalui arbitrase nasional, hal ini disebabkan mereka beranggapan lembaga arbitrase lebih menguntungkan dibanding dengan penyelesaian melalui lembaga litigasi pengadilan dengan beberapa alasan diantaranya waktu penyelesaian perkara lebih cepat dibanding dengan pengadilan negeri; hakimhakimnya atau para arbiternya yang ditunjuk mempunyai pengetahuan khusus karena disamping ahli hukum juga mempunyai keahlian dibidang lainnya. ${ }^{8}$

Suatu persetujuan arbitrase harus menetapakan jangka waktu, yaitu berapa lama perselisihan atau sengketa yang diajukan pada arbitrase harus diputuskan. Apabila para pihak tidak menentukan jangka waktu tertentu, jangka waktu penyelesaian ditentukan oleh aturan-aturan arbitrase setempat.

Menurut penjelasan pasal 64 Unndang-Undang Arbitrase, putusan arbitrase merupakan putusan final dan mengikat kepada para pihak, dengan demikian tidak dapat diajukan banding, kasasi atau peninjauan kembali. ${ }^{9}$ Maksud pengertian final menurut Circut Sutiarso, terhadap putusan tersebut tidak dapat diajukan upaya hukum lagi, biaya perkaranya lebihmurah

\footnotetext{
${ }^{6}$ Cicut Sutiarso, op.cit, hal. 170

${ }^{7}$ Ibid, hal. 170

${ }^{8}$ Cicut Sutiarso, Op. Cit, hal.154.

${ }^{9}$ Penjelasan Pasal 60 UU RI No.30 Tahun 1999 tentang Arbitrase dan Penyelesaian Alternatif Sengketa.
} 
sehubungan tidak dimungkinkan mengajukan upaya hukum, proses acaranya tidak terikat aturan formal, bisa mempersingkat batas waktu dan bisa dilaksanakan diruang, tempat atau gedung persidangan tertentu berdasarkan kesepakatan para pihak, dan proses persidangan serta pengambilan putusan dengan cara tertutup untuk umum, para pihak merasa lebih aman tidak terganggu adanya publikasi atau komentar-komentar selama proses berlangsung, adanya jaminan kerahasiaan sengketanya secara perorangan, dan rahasia perusahaan atau rahasia dagang bagi perusahaan yang sedang sengketa terhadap pihak lain. ${ }^{10}$

Penyelesaian sengketa melalui arbitrase merupakan cara yang paling di sukai oleh para penguasa karena dinilai sebagai cara yang paling serasi dengan kebutuhan dalam dunia bisnis, kecendurungan untuk menyelesaikan sengketa bisnis melalui arbitrase terlihat pada pencantuman arbitration clause (klausul arbitrase) dalam kontrak bisnis.

\section{Kelebihan dan Kelemahan Arbitrase}

Adapun kelebihan arbitrase dalam penyelesaian sengketa dibanding dengan peradilan umum adalah sebagai berikut:

1. Sidang arbitrase adalah tertutup untuk umum, sehingga kerahasiaan sengketa para pihak terjamin.

2. Kelambatan yang diakibatkan oleh hal prosedural dan administratif dapat dihindari.

3. Para Pihak yang bersengketa dapat memilih arbiter yang menurut keyakinannya mempuny6ai pengalaman, pengetahuan, jujur dan adil serta latar belakang yang cukup mengenal masalah yang disengketakan.

4. Sikap arbiter atau majelis arbiter dalam menangani perkara arbitrase didasarkan pada sikap yang mengusahakan win-win solution terhadap para pihak yang bersengketa.

5. Pilihan hukum untuk menyelesaikan sengketa serta proses dan tempat penyelenggaraan arbitrase dapat ditentutkan para pihak.

6. Putusan Arbitrase mengikat para pihak (finaland binding) dan dengan melalui tata cara (prosedur) sederhana ataupun langsung dapat dilaksanakan.

\footnotetext{
${ }^{10}$ Cicut Sutiarso, op.cit, hal. 154.
}

7. Suatu perjanjian arbitrase (klausul arbitrase) tidak menjadi batal karena berakhir atau batalnya perjanjian pokok.

8. Di dalam proses arbitrase, arbiter atau majelis arbitrase harus mengutamakan perdamaian diantara para pihak yang bersengketa.

Bahwa selain kelebihan yang dikemukakan di atas, juga terdapat kelemahan arbitrase, yaitu:

1. Putusan arbitrase ditentukan olleh kemampuan teknis arbiter untuk memberikan keputusan yang memuaskan sesuai dengan rasa keadilan para pihak.

2. Apabila pihak yang kalah tidak mau melaksanakan putusan arbitrase, maka diperlukan perintah dari pengadilan untuk melakukan eksekusi atas putusan arbitrase tersebut.

3. Pada praktiknya pengakuan dan pelaksanaan keputusan arbitrase asing masih menjadi hal yang sulit.

4. Pada umumnya pihak-pihak yang bersengketa di arbitrase adalah perusahaan-perusahaan besar, oleh karena itu untuk mempertemukan kehendak para pihak yang bersengketadan membawanya ke badan arbitrase tidak mudah.

\section{Keterkaitan Antara Arbitrase dengan Pengadilan.}

Pengadilan mempunyai beberapa keterkaitan dengan arbitrase, dalam hal ini dapat dilihat dari UU No. 30 Tahun 1999, yang mencantumkan beberapa peranan pengadilan di Indonesia untruk memperkuat proses arbitrase, dari pemeriksaan awal sampai pelaksanaan putusan arbitrase.

Menurut pasal 13 UU No. 30 Tahun 1999 tentang Arbitrase dan Penyelesaian Alternatif Penyelesaian Sengketa.

1) Dalam hal para pihak tidak dapat mencapai kesepakatan mengenai pemilihan arbiter atau tidak ada ketentuan yang dibuat mengenai pengangkatan arbiter, Ketua Pengadilan Negeri mununjuk arbiter atau majelis arbiter.

2) Dalam suatu arbitrase ad-hod bagi setiap ketidaksepakatan dalam penunjukan seorang atau beberapa arbiter, para pihak dapat mengajukan permohonan kepada Ketua Pengadilan Negeri untuk menunjuk seorang arbiter atau lebih dalam rangka penyelesaian sengketa para pihak. 
Dalam pembentukan majelis arbitrase, terdapat kemungkinan 2 arbiter yang telah ada, akan tetapi gagal untuk menunjuk arbiter ketiga, sebagaimana yang telah disepakat. Dalam hal ini, maka menurut Pasal 15 ayat (4) UU No.30 Tahun 1999 menyebuitkan bahwa atas permohonan satu pihak. Ketua Pengadilan Negeri dapat mengangkat arbiter ketiga. Adapun bunyi pasal 15 ayat (4) UU No.30 Tahun 1999 adaalah sebagai berikut:

"Dalam hal kedua arbiter yang telah ditunjuk masing-masing pihak sebagaimana dimaksud dalam ayat (1) tidak berhasil menunjuk arbiter ketiga dalam waktu 14 (empat belas) hari setelah arbiter yang terakhir ditunjuk, atas permohonan salah satu pihak, Ketua Pengadilan Negeri dapat mengangkat arbiter ketiga."

Kemudian berdasarkan ketentuan Pasal 22 ayat (1) UU No.30 Tahun 1999, terhadap arbiter dapat diajukan tuntutan ingkar apabila cukup alasan dan cukup bukti otentik yang menimbulkan keraguan bahwa arbiter akan melakukan tugasnya secara tidak bebas dan akan berpihak dalam mengambil keputusan. Lebih jau lagi, tuntutan ingkar terhadap seorang arbiter dapat pula dilaksanakan jika terdapat bukti adanya hubungan kekeluargaan, keuangan atau pekerjaan dengan salah satu pihak atau kuasanya. Hal ini seperti yang tercantum dalam pasal 22 ayat (2) UU No. 30 Tahun 1999 yang mengatakan sebagai berikut:

"Tuntutan ingkar terhadap seorang arbiter dapat pula dilaksanakan apabila terbukti adanya hubungan kekeluargaan, keuangan atau pekerjaan dengan salah satu pihak atau kuasanya."

Selanjutnya pada pasal 23 aya (1) UU No.30 Tahun 1999 menyatakan sebagai berikut:

"Hak ingkar terhadap arbiter yang diangkat oleh Ketua Pengadilan Negeri diajukan kepada Pengadilan Negeri yang bersangkutan.”

Jika tuntutan ingkar yang diajukan oleh salah satu pihak tidak disetujui oleh pihak yang berkepentingan dapat mengajukan tuntutan kepada Ketua Pengadilan Negeri yang putusannya mengikat kedua pihak, dan tidak dapat diajukan perlawanan. Jika ketua Pengadilan Negeri memutuskan bahwa tuntutan ingkar sesuai

dengan pasal 25 ayat (1) UU No. 30 Tahun 1999 beralasan, maka diangkatlah seorang arbiter pengganti sebagaimana yang berlaku untuk pengangkatan arbiter yang berlaku untuk pengangkatan arbiter yang digantikan.

Menurut ketentuan pasal 25 ayat (2) UU No.30 Tahun 1999 yang berbunyi sebagai berikut:

"Dalam hal Ketua Pengadilan Negeri memutuskan bahwa tuntutan sebagaimana dimaksud dalam ayat (1) beralasan, seorang arbiter pengganti harus diangkata dengan cara sebagaimana yang berlaku untuk pengangkatan arbiter yang digantikan."

Namun menurut pasal 25 ayat (3) UU No.30 Tahun 1999, dalam hal Ketua Pengadilan Negeri menolak tuntutan ingkar, arbiter melanjutkan tugasnya. Peranan lain dari Pengadilan Negeri merupakan tempat pendaftaran putusan arbitrase nasional. Hal ini sebagaimana dinyatakan dalam pasal 59 ayat (1) UU No.30 Tahun 1999, sebagai berikut:

"Dalam waktu paling lama 30 (tiga puluh) hari terhitung sejak tanggal putusan diucapkan, lembar asli atau salinan otentik putusan arbitrase diserahkan dan di daftarkan oleh arbiter atau kuasanya kepada Panitera Pengadilan Negeri."

Penyerahan dan pendaftaran sebagaimana dimaksud dalam pasal 59 ayat (1) UU No.Tahun 1999 tersebut dilakukan dengan pencatatan dan penandatanganan pada bagian akhir atau dipenggir putusan oleh panitera pengadilan negeri dan arbiter atau kuasanya yang menyerahkan, dan catatan tersebut merupakan akta pendaftaran.

Sehingga adapat dikatakan keterkaitan antara arbitrase dengan pengadilan sangat begitu terikat, dalam arti penyelesaian putusan arbitrase, pelaksanaan haruslah berdarkan perintah Pengadilan negeri.

\section{Pelaksanaan Putusan Arbitrase.}

Seperi putusan-putusan pengadilan lainnya, maka putusan arbitrase harus pula memuat kepala Putusan yang berbunyi: "Demi keadilan berdasar- kan KeTuhanan Yang Maha Esa. "Menurut Sudikno Mertokusumo, Kepala putusan ini memberikekuatan eksekutorial pada putusan. ${ }^{11}$

\footnotetext{
${ }^{11}$ Sudikno Mertokusumo, Op.Cit, hal. 302
} 
Disamping itu harus memuat pula pendapat tiaptiap anggota arbitrase dalam hal terdapat perbedaan pendapat dalam majelis arbitrase (pasal 54). Jadi kalu ada perbedaan pendapat diantara para anggota, maka perbedaan itu harus dicatat dalam putusan.

Putusan arbitrase bersifat final dan mempunyai kekuatan hukum tetap dan mengikat para pihak (pasal 60), Final berati bahwa putusannya tidak dapat dimintakan banding, kasasi atau Peninjauan kembali. Putusan arbitrase diserahkan dan didaftarkan oleh arbiter atau kuasanya kepada Panitera Pengadilan Negeri. Putusan arbiter hanya mempunyai kekuatan eksekutorial setelah memperoleh izin atau perintah untuk dieksekusi dari pengadilan. ${ }^{12}$

Dalam hal para pihak tidak melaksanakan putusan arbitrase secara sukarela, putusan dilaksanakan berdasarkan Perintah Ketua Pengadilan Negeri atas permohonan salah satu pihak yang bersangkutan. Dalam hal ini Pengadilan Negeri tidak diperkenankan untuk memeriksa pokok perkaranya lagi, dan tidak memeriksa alasan atau pertimbangan dari putusan arbitrase. Tugasnya hanyalah mengizinkan atau menolak eksekusi. Kalau menolak eksekusi alasannya secara limitatif tercantum dalam pasal 62 ayat (4) UU No.30 Tahun 1999. Ini tidak lain dimaksudkan agar putusan arbitrase tersebut benar-benar mandiri, final, dan mengikat. ${ }^{13}$

Pada prinsipnya eksekusi merupakan tindakan paksa yang dilakukan pengadilan dengan bantuan alat perlengkapan negara, guna menjalankan putusan arbitrase yang memperoleh kekuatan hukum tetap. Putusan yang dapat di eksekusi adalah putusan yang telah memperoleh kekuatan hukum tetap, karena didalam putusan yang telah mempunyai kekuatan hukum tetap telah terkandung wujud hubungan hukum yang tetap dan pasti diantara pihak-pihak yang berperkara.

Di dalam praktek di Indonesia yang dilakukan oleh para arbiter BANI ternyata sedikit berbeda dengan apa yang diatur dalam UU No.30 Tahun 1999 yang mewajibkan kepada arbiter atau kuasanya segera mendaftarkan putusannya ke Pengadilan Negeri. Menurut aturan yang dijadikan pedoman BANI,

arbiter atau majelis arbitrase bisa memberikan hak kepada para pihak yang melaksanakan putusan seca-

\footnotetext{
${ }^{12}$ Sudikno Mertokusumo, Ibid. hal. 367

${ }^{13} \mathrm{Ibd}$, hal. 68
}

ra sukarela dalam tenggang waktu yang ditentukan selama masa 30 hari untuk pendaftaran putusan, apabila sudah menjelang tenggang waktu yang ditentukan para pihak ternyata tidak melaksanakan secara suka rela, maka barulah putusan tersebut diserahkan kepada Pengadilan Negeri untuk dilakukan pendaftaran sesuai dengan prosedur yang berlaku. Selanjutnya Ketua Pengadilan Negeri akan mendaftar dan memfiat eksekusi putusan tersebut dengan suatu putusan Pengadilan dengan cara memuat suatu catatan di Kepala Putusan arbitrase yang berbunyai "Demi Keadilan Berdasarkan Ke-Tuhanan Yang Maha Esa "Dengan fiat eksekusi seperti ini, putusan arbitrase tersebut sudah dapat dijalankan sebagaimana menjalankan putusan Pengadilan Negeri. ${ }^{14}$

Perbedaan cara pendaftaran yang dilakukan BANI dalam praktik dengan ketentuan UU adalah kalau menurut Pasal 59 UU No.30 Tahun 1999 pendaftaran harus dilakukan dalam jangka waktu satu bulan, meskipun belum ada kepastian apakah para pihak mau melaksanakan putusan arbitrase secara sukarela atau tidak. Sedangkan menurut pasal 17 dan 18 Peraturan Prosedur BANI pendaftaran baru dilakukan setelah para pihak tidak mau menjalankan putusan arbitrase secara sukarela sampai dengan batas jangka waktu tertentu yang telah ditetapkan sebelum tenggang waktu pendaftaran berakhir. ${ }^{15}$

Kewajiban para pihak di dalam pendaftaran putusan adalah membayar biaya pendaftaran yang besarnya ditentukan oleh Ketua Pengadilan Negeri yang bersangkutan, ternyata di dalam praktik tidak ada keseragaman jumlah antara pengadilan yang satu dengan yang lain, sehingga membawa akibat pula kepada jumlah biaya yang harus dibebankan para pihak oleh lembaga arbitrase ketika arbiter atau anggota majelis arbitrase atau kuasanya. ${ }^{16}$

Frans Hendra Winarta, bertpendapat dengan berfatokan kepada ketentuan peraturan perundangundangan secara normatif, dengan mengemukakan, eksekusi putusan arbitrase akan hanya dilaksanakan jika putusan arbitrase tersebut telah sesuai dengan perjanjian arbitrase dan memenuhi persyaratan yang

\footnotetext{
${ }^{14}$ Wawancara dengan Priyatna Abdurrasyid, Januari 2010, dalam Cicut Sutiarso, Pelaksanaan Putusan Arbitrase Dalam Sengketa Bisnis, Jakarta: Yayasan Pustaka Obor Indonesia, 2011, hal.172173

${ }^{15}$ Cicut Sutiarso, Op.Cit, hal.173

${ }^{16}$ Cicut Sutiarso, hal.174
} 
ada di UU No.30 Tahun 1999 serta tidak bertentangan dengan kesusilaan dan ketertiban umum. ${ }^{17}$

\section{Pembatalan Putusan Arbitrase}

Sebekum sengketa dibidang bisnis diselesaikan melalui arbitrase, para pihak telah lebih dulu sepakat agar penyelesaian sengketa diselesaikan melalui arbitrasesebagaimana diatur pada pasal 2 UU No.30 Tahun 1999, undang-undang ini mengatur penyelesaian sengketa atau beda pendapat antara para pihak dalam suatu hubungan hukum tertentu yang telah mengadakan perjanjian arbitrase yang secara tegas menyatakan bahwa semua sengketa atau beda pendapat yang timbul atau yang mungkin timbul dari hubungan hukum tersebut akan diselesaikan dengan cara arbitrase atau melalui alternatif penyelesaian sengketa. Dalam istilah hukum yang disebut Pactum de Compromettindo, yang dapat diartikan kesepakatan para pihak sebelum sengketa terjadi, selain itu pada Pasal 9 ayat (1) UU No.30 Tahun 1999 mengemukakan “ Dalam hal para pihak memilih penyelesaian sengketa arbitrase setelah sengketa terjadi, persetujuan mengenai hal tersebut harus dibuat dalam suatu perjanjian tertulis yang ditanda tangani oleh para pihak yang disebut dengan Akta Kompromis, akta tersebut dibuat para pihak setelah terjadi sengketa.

Sebagaimana dikemukakan diatas, dan berdasarkan ketentuan pasal 60 UU No.30 Tahun 1999 putusan arbitrase bersifata final dan mempunyai kekuatan hukum tetap dan mengikat para pihak. Selanjutnya berdasarkan penjelasan pasal 60 undang-undang tersebut mengemukakan putusan arbitrase merupakan putusan final dan dengan demikian tidak dapat diajukan banding, kasasi atau peninjauan kembali.

Bahwa pada sisi lain dalam undang-undang tersebut diatur juga tentang pembatalan putusan arbitrase. Pembatalan putusan arbitrase sendiri diartikan sebagai suatu upaya hukum yang diberikan kepada para pihak yang bersengketa untuk meminta kepada pengadilan negeri agar suatu putusan arbitrase dibatalkan baik terhadap sebagian atau seluruh putusan.

Dalam proses pembatalan putusan arbitrase, pengadilan tidak berwenang untuk memeriksa pokok perkara. Kewenangan pengadilan terbatas hanya

\footnotetext{
${ }^{17}$ Frans Hendra Winarta, Hukum Penyelesaian Sengketa, Arbitrase Indonesia dan Internasional, loc.cit, hlm72.
}

pada kewenangan memeriksa, keabsahan pengambilan prosedur pengambilan putusan arbitrase, antara lain proses pemilihan arbiter hingga pemberlakuan hukum yang di8pilih oleh para pihak dalam penyelesaian sengketa. ${ }^{18}$

Pembataalan putusan arbitrase diatur oleh UU No.30 Tahun 1999 tentang Arbitrase dan Alternatif Penyelesaian Sengketa yaitu di dalam Bab vii, Pasal 70, 71 dan 72, meskipun hanya terdiri dar 3 (tiga) pasal, namun cukup menunjukkan betapa eratnya hubungan proses penyelesaian sengketa melalui arbitrase dengan peranan Pengadilan Negeri dalam kaitannya dengan pelaksanaan putusan yang dimohonkan pembatalan oleh pihak yang tidak puas.

Pada pasal 70 UU No.30 Tahun 1999 menyatakan dengan tegas tentang alasan dan keadaan yang dapat dipergunakan untuk mengajukan permohonan pembatalan putusan arbitrase. Selanjutnya Pasal 71 dan Pasal 72 menyebutkan adanya hubungan antara Pengadilan Negeri dengan Pembatalan putusan arbitrase tersebut.

Perrmohonan pembatalan putusan arbitrase harus diajukan secara tertulis kepada Ketua Pengadilan Negeri dalam waktu 30 (tiga puluh) hari terhitung sejak hari pendaftaran putusan arbitrase kepada Panitera Pengadilan Negeri. Dalam hal permohonan pembatalan dikabulkan, maka Ketua Pengadilan dalam waktu 30 (tiga puluh) hari menentukan lebih lanjut apakah pembatalan tersebut berlaku seluruhnya ataukah hanya sebagian dan bagi yang tidak puas terhadap putusan Pengadilan Negeri tersebut dapat mengajukan upaya hukum banding ke Mahkamah Agung yang memeriksa pada tingkat pertama dan terakhir, selanjutnya Mahkamah Agung mempertimbangkan serta memutuskan permohonan banding tersebut dalam waktu paling lama 30 (tiga puluh) hari terhitung sejak hari penyerahan dan pendaftaran putusan arbitrase kepada Ketua Pengadilan Negeri.

Menurut Cicut Sutiarso, sehubungan dengan hal diatas dengan merujuk kepada teori hukum sebagai panglima didalam mewujudkan kepastian hukum dan keadilan dikaitkan pula dengan asas peradilan yang baik, bagi pihak yang sudah menang dan putusan berkekuatan hukum tetap, semestinya pelaksanaan putusan arbitrase terus dijalankan dan berlaku sebagai-

\footnotetext{
${ }^{18}$ Frans Hendra Winarta, ibid hlm 85.
} 
mana prosedur pelaksanaan putusan perkara perdata pada umumnya. ${ }^{19}$

Di dalam praktek telah banyak terjadi kasus pembatalan putusan yang berakibat, Ketua Pengadilan Negeri tidak berdaya untuk meneruskan tahap pelaksanaan putusan arbitrase. Keadaan ini dikhwatirkan akan menjadi faktor penghambat dan hilangnya minat para pelaku bisnis untuk memilih arbitrasesebagai alternatif penyelesaian sengketa, misalnya kasus: Antara Perusahaan Pertambangan Minyak Dan Gas Bumi (Pertamina) sebagai Penggugat melawan KARAHA BODAS COMPANY LLC sebagai Tergugat I dan PT. PLN (Pesero) sebagai Tergugat II, dengan Nomor Perkara No.: 86/Pdt.G/202/PN.JKT.PST, telah diputus oleh Pengadilan Negeri Jakarta Pusat, tanggal 27 Agustus 2002 (gugatan dikabulkan) kemudian dimohonkan banding/kasasi ke Mahkamah Agung dan telah diputus tanggal 08 Maret 2004 (membatalkan putusan pengadilan negeri Jakarta $\mathrm{Pu}$ sat dan menyatakan tidak berwenang), sehingga Penggugat mengajukan permohonan Peninjauan Kembali (PK) pada tanggal 04 Mei 2005, dan berkas dikirim ke Mahkamah Agung Tahun 2007 baru diputus oleh Hakim Peninjauan Kembali tanggal 27 Desember 2009. Sedangkan yang dimohonkan pembatalan putusan arbitrase internasional Arbitration Prosedure Under The UNCITRAL Arbitration yaitu " Arbitral Tribunal/Fitnal Award in Rules "yang diputuskan di Genewa/Swiss, pada tanggal 18 Desember 2000, menurut Cicut Sutiarso, jika dihitung sampai tahun 2011 sudah memakan waktu 9 tahun belum juga dinikmati hasilnya. ${ }^{20}$ Disamping kasus sebagaimana dikemukkakan diatas masih banyak lagi ditemukan kasus yang merupakan kompetensi Arbitrase untuk memeriksa dan memutuskannya, akan tetapi akhirnya diselesaikan melalui peradilan umum. Untuk efektinya penyelesaian sengketa bisnis melalui melalui Arbitrase Dan Alternatif Penyelesaian Sengketa harus diikuti itikad baik para pihak yang bersengketa untuk mematuhi dan melaksanakan putusan, karena penyelesaiannya juga didasarkan kepada ketentuan pasal 2 dan pasal 9 UU NO. 30 Tahun 1999 sebagaimana diuraikan diatas.

\footnotetext{
${ }^{19}$ Cicut Sutiarso, loc.cit, hlm 184

${ }^{20}$ Cicur Sutiarso, Ibid, hlm 187.
}

\section{Kesimpulan}

1. Masyarakat Indonesia di dalam menyelesaikan sengketa bisnisnya telah ada memilih melalui lembaga arbitrase nasional, hal ini disebabkan mereka beranggapan lembaga arbitrase lebih menguntungkan dibanding dengan penyelesaian melalui lembaga litigasi pengadilan dengan beberapa alasan, waktu penyele3saian perkara lebih cepat dibanding dengan pengadilan, hakim-hakimnya atau para arbiternya yang ditunjuk mempunyai pengetahuan khusus, karena disamping ahli hukum juga mempunyai keahlian dibidang lainnya, putusan arbitase bersifat final dan mempunyai kekuatan hukum tetap dan mengikat para pihak (final and binding).

2 a. Peraturan perundang-undangan yang mengatur tentang arbitrase ternyata juga memberikan peluang bagi pihak yang kalah untuk mengajukan permohonan pembatalan putusan atas putusanarbitrase, upaya hukum inillah yang sering digunakan oleh pihak yang kalah dan yang merasa tidak puas terhadap putusan arbitrase yang di dalam praktek menghabiskan waktu penyelesaian yang cukup panjang.

b. Pembatalan putusan arbitrase telah diatur tersendiri oleh UU No. 30 Tahun 1999 tentang Arbitrase dan Alternatif Penyelesaian Sengketa yaiitu di dalam Bab VII, Pasal 70, 71, 72, meskipun hanya terdiri dari 3 (tiga) pasal, namun cukup menunjukkan betapa erat hubungan proses penyelesaian sengketa melalui arbitrase dengan peranan Pengadilan Negeri dalam kaitannyas dengan pelaksanaan putusan yang dimohonkan pembatalan oleh pihak yang tidak puas.

\section{Saran}

1. Merujuk pada teori hukum sebagai panglima di dalam mewujudkan kepastian hukum dan keadilan dikaitkan pula dengan asas peradilan yang baik, bagi pihak yang sudah menang dan putusan telah berkekuatan hukum tetap, semestinya pelaksanaan putusan arbitrase terus dijalankan dan berlaku sebagaimana prosedur pelaksanaan putusan perkara perdata pada umumnya.

2. Ketua Pengadilan Negeri yang menerima permohonan Eksekusi dari pihak yang menang, dengan kewenangannya harus secara tegas harus 
melaksanakan Putusan Arbitrase tersebut, karena penyelesaian sengketa oleh para pihak didasarkan atas kesepakatan sebagaimana diatur dalam pasal 2 dan 9 UU NO: 30 Tahun 1999 tentang Penyelesaian Sengketa melalui Arbitrase dan Alternatif Penyelesaian Sengketa.

\section{Daftar Pustaka}

\section{Buku}

Circut Sutiarso, Pelaksanaan Putusan Arbitrase Dalam Sengketa Bisnis, Jakarta, Yayasan pustaka obor Indonesia, 2011

Frans Hendra Winata, Hukum Penyelesaian Sengketa Arbitrase Nasional Indonesia dan internasional, Jakarta, Sinar Grafika, 2012

Sudikno Mertokusumo, Hukum Acara Perdata Indonesia, Universitas Atmajaya Yogyakarta, 2010

\section{Peraturan Perundang-Undangan}

Undang-Undang RI No: 48 Tahun 2009 tentang Kekuasaan Kehakiman

Undang-Undang RI No: 30 Tahun 1999 tentang Arbitrase dan Alternatif Penyelesian Sengketa Peraturan Prosedur Arbitrase Badan Arbitrase Nasional Indonesia 